\title{
Implementasi Undang-undang No 6 Tahun 2014 tentang Desa Rancasenggang, Kecamatan Sindangkerta, Kabupaten Bandung Barat (Sosialiasi, Hambatan, dan Dampaknya)
}

\author{
Deden Suhendar \\ Dosen Universitas Al Ghifari Bandung
}

\begin{abstract}
Good governance has been an important discourse in the development administration and democracy studies during the last two decades.

The socialization process of Uu No. 6 of 2014 concerning Villages in Rancasenggang Village, Sindangkerta Subdistrict, West Bandung Regency, was carried out through a village law socialization program held by the Sindangkerta Subdistrict government, West Bandung Regency simultaneously with the village apparatus in all Sindangkerta Subdistrict, West Bandung Regency.

The obstacles experienced by village officials and the community in the implementation of the Village Law in Rancasenggang Village, Sindangkerta Subdistrict, West Bandung Regency, are the existence of multi-interpretation regulations that burden the village government and Sindangkerta District government, West Bandung District in distributing village funds.

The village apparatus in the implementation of the village law in the Rancasenggang Village Sindangkerta Subdistrict, West Bandung Regency, basically has understood the contents of the village law but has not been maximized because the socialization of the new village law was carried out once by the Sindangkerta District government, West Bandung Regency.
\end{abstract}

\section{Latar Belakang}

Dalam Undang-undang No 6 Tahun 2014 Pasal 1 ayat 1 ditegaskan bahwa desa sebagai kesatuan masyarakat hukum yang memiliki batas wilayah yang berwenang untuk mengatur dan mengurus urusan pemerintahan, kepentingan masyarakat setempat berdasarkan prakarsa masyarakat, hak asal usul, dan/atau hak tradisional yang diakui dan dihormati dalam sistem pemerintahan Negara Kesatuan Republik Indonesia. Desa memiliki hak asal usul dan hak tradisional dalam mengatur dan mengurus kepentingan masyarakat setempat dan berperan mewujudkan anggota masyarakat agar mencapai kesejahteraan. Dalam perjalanan ketatanegaraan Republik Indonesia, desa telah berkembang dalam berbagai bentuk sehingga perlu dilindungi dan diberdayakan agar menjadi kuat, maju, mandiri, dan demokratis sehingga dapat menciptakan landasan yang kuat dalam melaksanakan 
pemerintahan dan pembangunan menuju masyarakat yang adil, makmur, dan sejahtera. Sebagai lapisan terbawah dari struktur pemerintahan, aktivitas masyarakat di desa sudah semestinya mendapat kesempatan untuk mengembangkan potensi yang dimiliki.

Potensi wilayah dan penduduk desa menghadapi berbagai permasalahan dan tantangan semakin kompleks. Temuan hasil observasi yang telah dilakukan di Desa Rancasenggang, Kecamatan Sindangkerta, Kabupaten Bandung Barat, menunjukkan potensi sumber daya manusia dan wilayah yang dimiliki belum dapat dioptimalkan dalam mencapai kesejahteraan masyarakat. Terdapat beberapa fakta yang ditemukan, yaitu; 1) masyarakat lebih memilih mencari penghidupan sebagai buruh atau pekerja di pabrik, 2) banyak lahan warga yang berpotensi produktif sebagai tempat usaha namun tidak diberdayakan, 3) masyarakat Desa Rancasenggang belum mampu mengembangkan kreativitas dalam pengembangan kewirausahaan, dan 4) program pembangunan yang dirancang aparatur desa belum terencana dengan baik. Berbagai permasalahan nyata yang ditemukan di Desa Rancasenggang, semakin menguatkan tentang pentingnya kebijakan pemerintah dalam pemberdayaan potensi setiap desa.

Permasalahan klasik tentang pemberdayaan potensi desa, masih terjadi di Desa Rancasenggang, Kecamatan Sindangkerta, Kabupaten Bandung Barat. Ketidakmampuan masyarakat desa dalam memenuhi kebutuhan dasar (basic needs) disebabkan karena ketidaktersediaan lapangan pekerjaan, bergesernya fundamental ekonomi pedesaan yang bercorak agraris menjadi residential area dan adanya industri bukan padat karya melainkan padat modal dan tuntutan kemampuan SDM dalam rekayasa teknologi. Permasalahan keterbatasan potensi sumber daya alam juga mempengaruhi struktur ekonomi desa. Tingkat pendidikan yang kurang sehingga berdampak dalam mengkreasi potensi desa akibat lemahnya partisipasi masyarakat desa. Undang-undang tentang desa apabila diterapkan dengan baik dipastikan dapat mengatasi permasalahan desa secara berkelelanjutan.

Kebijakan pemerintah untuk mendorong percepatan pembangunan sumber daya manusia dan sarana prasarana di desa, telah dituangkan dalam Undang- 
undang No 6 Tahun 2014. Kebijakan yang diatur dalam undang-undang desa tidak sebatas besarnya anggaran yang diberikan untuk setiap desa, melainkan kewenangan luas bagi masyarakat desa untuk mengembangkan segala potensi yang dimiliki. Aparatur desa dan masyarakatnya dipacu untuk melakukan percepatan mencapai taraf kesejahteraan dengan pembiayaan sektor-sektor industri kreatif sehingga membuka lapangan pekerjaan baru. Sarana dan prasarana yang bersifat fisik didorong untuk mempercepat akses menuju pusat ekonomi sehingga hasil pertanian, perkebunan dan industri kreatif masyarakat segera dapat di pasarkan. Dalam undang-undang desa, masyarakat didorong untuk meningkatkan kualitas sumber daya manusia melalui pendidikan dan kesehatan. Menurut Syahza (200) setiap anggota masyarakat di desa, apabila didorong untuk menempuh pendidikan, dapat membentuk masyarakat yang kuat, maju dan mandiri melalui pemberdayaan potensi yang dimiliki setiap desa. Kebijakan undang-undang desa sangat strategis sehingga dalam implementasinya perlu dilakukan kajian agar mencapai target yang ditetapkan pemerintah pusat.

Kesiapan aparatur dan masyarakat desa dalam mengimplementasikan undang-undang desa perlu dilakukan pengkajian, mengingat hasil observasi yang dilakukan di Desa Rancasenggang, Kecamatan Sindangkerta, Kabupaten Bandung Barat, terdapat fakta-fakta yang menggambarkan betapa kompleknya permasalahan yang terdapat di desa. Sebagai kebijakan baru, undang-undang desa berpotensi mengalami berbagai hambatan bahkan kegagalan, apabila tidak dilakukan kajian yang berorientasi pada kesiapan aparatur desa dan masyarakat dalam mengimplementasikannya. Undang-undang desa menjadi sangat penting untuk diimplementasikan secara benar, agar upaya percepatan kesejahteraan masyarakat terealisasi dengan baik. Peran aktif setiap anggota masyarakat di desa, menjadi faktor penentu keberhasilan implementasi undang-undang desa. Realitanya masih terdapat pembangunan desa yang lambat karena kurangnya pemahaman tentang pentingnya pembangunan desa, baik perangkat desa maupun masyarakat.

Kebijakan tentang desa yang diatur dalam undang-undang desa harus dapat dipastikan terealisasi. Dampak yang diperoleh melalui implementasi 
undang-undang desa, dapat mempercepat proses pembangunan untuk mencapai kesejahteraan masyarakat. Mengingat pentingnya realisasi undang-undang desa, maka dilakukan penelitian untuk menganalisis implementasi undang-undang desa dengan menganalisis proses sosialisasi, mengidentifikasi hambatan dan kesiapan aparatur desa dalam implementasi Undang-undang Desa di Desa Rancasenggang Kecamatan Sindangkerta, Kabupaten Bandung Barat.

\section{Rumusan Masalah}

Permasalahan dalam penelitian ini adalah;

1. Bagaimana proses sosialisasi Undang-undang No 6 Tahun 2014 tentang Desa di Desa Rancasenggang Kecamatan Sindangkerta, Kabupaten Bandung Barat?

2. Apa saja hambatan yang dialami oleh aparatur desa dan masyarakat dalam implementasi Undang-undang Desa di Desa Rancasenggang Kecamatan Sindangkerta, Kabupaten Bandung Barat?

3. Bagaimanakah kesiapan aparatur desa dalam implementasi Undang-undang Desa di Desa Rancasenggang Kecamatan Sindangkerta, Kabupaten Bandung Barat?

Penelitian dibatasi untuk mengkaji proses sosialiasi, hambatan dan dampak, karena ketiga aspek dapat menggambarkan kesiapan dan dampak dari implementasi undang-undang desa. Percepatan pembangunan masyarakat desa dalam penelitian ini diukur berdasarkan; rencana pembangunan desa yang disusun oleh aparatur desa, bentuk prakarsa masyarakat dalam pembangunan, tata kelola dan pemberdayaan potensi desa, kualitas pelayanan dan pengelolaan keuangan desa.

\section{Tujuan Penelitian}

Penelitian bertujuan untuk:

1. Mengkaji proses sosialisasi Undang-undang No 6 Tahun 2014 tentang Desa di Desa Rancasenggang, Kecamatan Sindangkerta, Kabupaten Bandung Barat. 
2. Mengetahui hambatan-hambatan yang dialami oleh aparatur desa dan masyarakat dalam implementasi Undang-undang Desa di Desa Rancasenggang, Kecamatan Sindangkerta, Kabupaten Bandung Barat.

3. Mengetahui kesiapan aparatur desa dalam mengimplementasikan Undangundang Desa dalam percepatan pembangunan masyarakat desa di Desa Rancasenggang Kecamatan Sindangkerta, Kabupaten Bandung Barat.

\section{Metode Penelitian}

Penelitian dirancang dengan metode deskriptif kualitatif untuk mengumpulkan data dan fakta penelitian tentang implementasi Undang-Undang Nomor 6 tahun 2014 tentang Desa terhadap percepatan pembangunan masyarakat di Desa Rancasenggang, Kecamatan Sindangkerta, Kabupaten Bandung Barat. Lokasi penelitian yang dipilih adalah di Desa Rancasenggang, Kecamatan Sindangkerta, Kabupaten Bandung Barat.

Pengumpulan data penelitian digunakan metode wawancara dan angket yang mendalam untuk memperoleh informasi tentang Implementasi Undangundang No 6 Tahun 2014. Nara sumber dalam penelitian ini adalah Kepala Desa dan Perangkat Desa yang merupakan unsur penyelenggara pemerintah desa. Dari hasil wawancara peneliti akan memperoleh data terkait pemahaman mereka tentang Undang-undang No 6 Tahun 2014, hambatan-hambatan dalam mengimplementasikan Undang-undang No 6 Tahun 2014, serta kesiapan aparatur desa dalam implementasi undang-undang desa di Desa Rancasenggang, Kecamatan Sindangkerta, Kabupaten Bandung Barat. Selain Kepala Desa dan Perangkat Desa peneliti juga akan menggabungkan sumber opini lain sebagai penguat argumentasi, penulis menggunakan data sekunder yang diambil dari Laporan Desa, buku, koran, dan jurnal terkait untuk pengembangan analisis.

\section{Tinjauan Pustaka}

\section{Undang-Undang Nomor 6 Tahun 2014 tentang Desa}

Pendekatan Pembangunan Desa sesuai dengan Undang-undang Nomor 6 Tahun 2014 tentang desa, membagi kedalam 2 jenis pendekatan yaitu desa 
membangun dan pembangunan desa yang diintegrasikan dalam perencanaan Pembangunan Desa. Pembangunan desa meliputi tahap perencanaan, pelaksanaan, dan pengawasan.

Pembangunan Desa bertujuan untuk meningkatkan kesejahteraan masyarakat desa dan kualitas hidup manusia serta penanggulangan kemiskinan melalui pemenuhan kebutuhan dasar, pembangunan sarana dan prasarana desa, pengembangan potensi ekonomi lokal, serta pemanfaatan sumber daya alam dan lingkungan secara berkelanjutan. Pembangunan desa mengedepankan kebersamaan, kekeluargaan, dan kegotongroyongan guna mewujudkan perdamaian dan keadilan sosial.

\section{Pembangunan Desa}

Konsep pembangunan merupakan konsep yang sangat multidimensional, yang mengacu kepada serangkaian karakteristik dan segenap aspek kehidupan, baik aspek politik, ekonomi, maupun sosial. Menurut Todaro dalam Bryant abd White (1998) pembangunan adalah proses multidimensi yang mencakup perubahan-perubahan penting dalam struktur sosial, sikap rakyat dan lembagalembaga nasional dan juga akselerasi pertumbuhan ekonomi, pengurangan kesenjangan, dan pemberantasan kemiskinan ${ }^{55}$. Proses pembangunan nasional tentunya dimulai dari pembangunan pada kelompok masyarakat paling kecil, yaitu desa. Desa merupakan ujung tombak dari sukses atau tidaknya implementasi otonomi daerah.

Undang-undang No 32 Tahun 2004 tentang Pemerintahan Daerah menegaskan seiring dengan diterapkannya arus desentralisasi, paradigma pembangunan nasional telah mengalami perubahan, dari pembangunan yang bertumpu pada negara menjadi pembangunan yang bertumpu pada masyarakat.

Isu strategis 2014-2019 dalam perencanaan pembangunan desa, di antaranya:

1. Masih rendahnya aksesbilitas masyarakat miskin terhadap pelayanan pendidikan dan kesehatan;

\footnotetext{
${ }^{55}$ Bryant Coralie dan White Louise. Manajemen pembangunan.1998.LP3ES, Jakarta : 34
} 
2. Peningkatan ketahanan pangan;

3. Peningkatan iklim investasi daerah;

4. Rendahnya kualitas dan kuantitas infrastruktur wilayah;

5. Kerentanan wilayah terhadap bencana alam;

6. Tingginya kemiskinan;

7. Tingginya angka pengangguran;

8. Belum maksimalnya kinerja aparatur daerah.

Isu-isu strategis di atas membuktikan bahwa masih banyak hambatan dalam melaksanakan pembangunan desa. Hasil penelitian terdahulu menyatakan bahwa penghambat pembangunan desa adalah karena kualitas sumber daya manusia (pemerintah desa dan masyarakat) yang masih rendah, baik itu tingkat pengetahuan, kemampuan, pembiayaan, infrastruktur serta kemauan dari aparatur $\operatorname{desa}^{56}$.

Pembangunan desa mempunyai peranan yang sangat penting dan strategis dalam rangka pembangunan nasional dan pembangunan daerah karena di dalamnya terkandung unsur pemerataan pembangunan dan hasil-hasilnya, serta menyentuh secara langsung kepentingan masyarakat yang bermukim di perdesaan.

\section{Hasil Penelitian dan Pembahasan}

\section{Hasil Penelitian}

Penelitian dimulai dari tahap persiapan penelitian yang sudah dilakukan oleh peneliti, dimulai dengan,

a. Mempelajari UU No 6 tahun 2014 tentang Desa, dari pemahaman tentang undang-undang desa akan mampu memahami konsep dan tujuan dari undangundang desa, yang salah satunya adalah untuk mempercepat proses pembangunan desa;

b. Menyusun daftar pertanyaan yang digunakan untuk pelaksanaan interview, baik untuk perangkat desa maupun masyarakat setempat;

\footnotetext{
56 Nurliana. 2013. Pengelolaan Alokasi Dana Desa (ADD) Dalam Pembangunan fisik di Desa Sukomulyo Kecamatan Sepaku Kabupaten Penajam Paser Utara. Jurnal Administrasi Negara Volume 1, Nomor 3, 2013 : 1059-1070.Universitas Mulawarman.
} 
c. Menentukan aparatur desa di Desa Rancasenggang sebagai responden;

d. Mengurus perijinan untuk pengambilan data penelitian;

e. Menyusun instrumen penelitian untuk mendapatkan jawaban dari rumusan masalah dalam penelitian.

Tahapan persiapan penelitian diharapkan mempermudah peneliti dalam pengambilan data pelitian. Selanjutnya tahapan pelaksanaan penelitian, dimulai dengan melakukan interview dengan aparatur desa dan masyarakat setempat untuk menggali informasi tentang proses sosialisasi Undang-undang No 6 Tahun 2014 tentang Desa di Desa Rancasenggang Kecamatan Sindangkerta, Kabupaten Bandung Barat, mengidentifikasi hambatan dalam implementasi Undang-undang Desa di Desa Rancasenggang Kecamatan Sindangkerta, Kabupaten Bandung Barat, mengukur kesiapan aparatur desa dalam implementasi Undang-undang desa di Desa Rancasenggang Kecamatan Sindangkerta, Kabupaten Bandung Barat.

\section{Kondisi Masyarakat Desa Rancasenggang}

Penduduk Desa Rancasenggang berdasarkan data terakhir Th. 2015 sebanyak 5.531 jiwa, hasil Sensus Penduduk Th. 2017 sebanyak 5.434 jiwa, th 2016 sebanyak 5.408, sehingga mengenai penduduk Desa Rancasenggang mengalami kenaikan untuk setiap tahunnya rata-rata $2 \%$,

Jumlah Kelahiran Bayi (Persalinan) pada Tahun 2015 adalah sebanyak 44 jiwa, terdiri dari bayi lahir hidup 42 orang dan bayi lahir mati adalah 2 orang/jiwa.

Pendidikan merupakan salah satu modal dasar pembangunan, sehingga pendidikan adalah sebuah investasi (modal) pada masa yang akan datang. Di Desa Rancasenggang jumlah guru tahun 2016 berjumlah 61 orang.

Tantangan yang dihadapi dalam pembangunan kesejahteraan sosial meliputi proses globalisasi dan industrialisasi serta krisis ekonomi dan politik yang berkepanjangan. Dampak yang dirasakan di antaranya semakin berkembang dan meluasnya bobot, jumlah, dan kompleksitas berbagai permasalahan sosial.

Berkaitan dengan perkembangan situasi dan kondisi ketenagakerjaan di Desa Rancasenggang sampai akhir tahun 2017, masih menunjukkan keadaan kondusif, walapun di pihak lain masih dihadapkan pada keterbatasan lapangan 
kerja dan jumlah pencari kerja yang cukup banyak. Keadaan ini semakin sulit dikendalikan sebagai akibat krisis ekonomi dan kenaikan harga BBM dan banyaknya pencari kerja di Desa Rancasenggang adalah sebagai akibat penambahan angkatan kerja baru dan Pemutusan Hubungan Kerja (PHK). Kondisi ini terus berlangsung di berbagai lapisan dan tingkatan sektor-sektor usaha strategis yang banyak menyerap tenaga kerja. Keadaan seperti ini memberikan kontribusi sangat besar terhadap jumlah pencari kerja yang tidak terproyeksikan sebelumnya.

Jumlah angkatan kerja pada tahun 2017 sebanyak 417 orang dan tersalurkan dan ditempatkan di perusahaan-perusahaan maupun jenis pekerjaan lainnya sebanyak 48 orang, sedangkan sisanya 200 orang belum mendapat pekerjaan.

Pada tahun 2017 jumlah pencari kerja laki-laki sebesar 135 orang dan pencari kerja perempuan 65 orang, untuk tenaga kerja perempuan setiap tahunnya lebih banyak tersalurkan terutama ke perusahaan-perusahaan tekstil dan garmen yang memprioritaskan tenaga kerja perempuan.

Dari segi pendidikan lulusan SLTA menempati urutan tertinggi dari jumlah persentase pencari kerja yang berhasil diterima dan ditempatkan sebagai karyawan di perusahaan ataupun di tempat kerja lainnya mencapai $40 \%$.

Dalam hal penyerapan tenaga kerja, jumlah tenaga kerja yang ditempatkan mengalami kenaikan dibandingkan dengan tahun sebelumnya, sementara jumlah pencari kerja yang terdaftar mengalami penurunan.

Dalam hal kepemudaan, pada tahun 2017 tidak terldepas dari aktivitas dan eksistensi Karang Taruna baik level desa maupun level RW, sedangkan jumlah anggota Karang Taruna aktif untuk level desa meskipun telah terbentuk namun sampai saat belum memperlihatkan eksistensinya.

Sedangkan organisasi keolahragaan yang ada di Desa Rancasenggang cukup variatif, baik yang dikelola secara profesional, semi profesional maupun semua organisasi tersebut masih dikelola secara amatir, namun kebanyakan hanyalah penyaluran dari kegemaran saja. 
Kebudayaan yang ada di Desa Rancasenggang merupakan modal dasar pembangunan yang melandasi pembangunan yang akan dilaksanakan, warisan budaya yang bernilai luhur merupakan dasar dalam rangka pengembangan pariwisata budaya yang dijiwai oleh mayoritas keluhuran nilai Agama Islam.

Pihak pemerintahan desa terus membina kelompok dan organisasi kesenian yang ada, meskipun dengan keterbatasan dana yang dialokasikan namun para pewaris kebudayaan di Desa Rancasenggang terus merawat dan melestarikannya, seperti akhir-akhir ini membentuk ikatan olahraga dan seni Formi mulai dari tingkat desa sampai tingkat Kabupaten Bandung Barat, sehingga kelompok-kelompok kesenian tersebut terus terpelihara, apalagi pada tahun 2012 telah dibentuk Paguyuban Budaya Gupay Tugu Setra, yang salah satu tujuannya mengikat dan mengembangkan kelompok-kelompok seni dan budaya di Desa Rancasenggang.

Di bidang pariwisata, Desa Rancasenggang tidak mempunyai tempat wisata yang bisa diandalkan, namun demikian pemerintah Desa Rancasenggang tidak berputus asa bersama-sama dengan masyarakatnya terus melestarikan dan berencana membangun sarana wisata yang bisa diandalkan untuk Desa Rancasenggang. Di samping itu pula masih banyak budaya-budaya yang dahulu sempat ada dan tenggelam untuk diangkat lagi, sehingga generasi berikutnya akan teringat kembali semua hal-hal yang pernah ada pada leluhur mereka (di Desa Rancasenggang, Kecamatan Sindangkerta, Kabupaten Bandung Barat).

Tempat peribadatan yang ada di Desa Rancasenggang, Kecamatan Sindangkerta, Kabupaten Bandung Barat hanyalah tempat peribadatan untuk orang Muslim saja, karena penduduk desa Rancasenggang hampir $100 \%$ beragama Islam. 


\section{Proses Sosialisasi Undang-undang No 6 Tahun 2014 tentang Desa di Desa Rancasenggang, Kecamatan Sindangkerta, Kabupaten Bandung Barat}

Pengetahuan aparatur desa tentang Undang-undang No 6 tahun 2014 tentang Desa dari hasil interview dengan Kepala Desa dan aparatur serta beberapa warga masyarakat diketahui bahwa pada dasarnya sosialisasi tentang undang-undang desa di Desa Rancasenggang sudah dilaksanakan tetapi belum maksimal, sehingga pemahaman aparatur desa tentang Undang-undang Desa dapat dikatakan minim/kurang. Hal ini dipengaruhi oleh tingkat pendidikan SDM aparatur desa karena pendidikan Kepala Desa hanya sampai pada Sekolah Menengah Atas. Kurangnya pemahaman terhadap Undang-undang Desa menyebabkan implementasi Undang-undang Desa belum maksimal.

Aparatur desa memperoleh sosialisasi undang-undang desa hanya sekali melalui program sosialiasasi dari pemerintah Kecamatan Sindangkerta, Kabupaten Bandung Barat, pemerintah desa juga mendapatkan buku panduan tentang Undang-undang No 6 Tahun 2014. Hasil sosialisasi undang-undang desa ternyata tidak hanya memberikan penjelasan tentang undang-undang desa tetapi juga memberikan jaminan kesehatan bagi para aparatur desa di Kecamatan Sindangkerta, Kabupaten Bandung Barat, diharapkan dengan diberikannya jaminan kesehatan, kinerja aparatur desa semakin giat. Selain sosialisasi dari pemerintah Kecamatan Sindangkerta, Kabupaten Bandung Barat, belum ada lembaga lain yang memberikan sosialisasi tentang Undang-undang Desa.

Pemahaman para aparatur desa terhadap undang-undang desa dinilai belum maksimal karena hanya dilaksanakan sekali oleh pemerintah Kecamatan Sindangkerta, Kabupaten Bandung Barat, sehingga masih banyak perangkat desa yang mengalami kesulitan untuk menerapkan Undang-undang Desa yang baru. Hal ini tentunya menjadi kendala tersendiri dalam mengimplementasikan Undangundang Desa. 


\section{Hambatan-Hambatan yang Dialami Oleh Aparatur Desa dalam Mengimplementasikan Undang-Undang Desa di Desa Rancasenggang, \\ Kecamatan Sindangkerta, Kabupaten Bandung Barat}

Undang-undang Desa termasuk katagori undang-undang baru, karena diundangkan pada tahun 2014, sehingga dalam pelaksanaannya masih banyak kendala. Kendala yang dijumpai oleh aparatur desa di antaranya terkait dengan pemahaman Undang-undang Desa, mekanisme pencairan dana desa, dan pengalokasian dana desa. Pemerintah pusat membuat kebijakan untuk menghindari kebingungan para aparatur desa untuk menyalurkan dana desa, dana desa difokuskan untuk infrastruktur, irigasi, dan sosial kemasyarakatan.

Implementasi Undang-undang Desa tentunya menjumpai kendala atau hambatan, kendala yang dialami para aparatur desa dalam melaksanakan undangundang desa di antaranya dari hasil wawancara dengan Kepala Desa Rancasenggang, dalam mengimplementasikan Undang-undang Desa disadari masih banyak aparatur desa yang belum memahami tentang isi dari Undangundang Desa, bukan hanya di Desa Rancasenggang tetapi juga di desa lain. Hal ini menyebabkan aparatur desa tidak bisa menjalankan aturan yang baru ini, tentunya menjadi kendala tersediri bagi aparatur desa.

Dari hasil wawancara juga diketahui bahwa kendala dalam menjalankan Undang-undang Desa adalah:

a. Perangkat desa sangat berhati-hati dalam pengelolaan desa, karena dari undang-undang desa tersebut pemerintah Kecamatan Sindangkerta, Kabupaten Bandung Barat sepakat untuk membuat program pembangunan dan pengelolaan dana desa, yaitu untuk tahun 2017 dana desa difokuskan pada perbaikan dan pembangunan infrastruktur, irigasi, dan dana sosial.

b. Perangkat desa menunggu keputusan dari pemerintah desa karena pembangunan harus dilaksanakan secara serentak.

c. Perangkat desa masih bingung tentang undang-undang desa, khususnya terkait tentang dana desa, apakah berlanjut setiap tahun, atau hanya berlaku untuk tahun 2017. Sejauh ini dana desa yang ditargetkan $10 \%$ baru sekitar $0,5 \%$, sehingga penggunaan dana harus hati-hati. 
Pendapat dari Bapak Dede salah seorang aparatur di Desa Rancasenggang tentang hambatan dalam implementasi Undang-undang Desa adalah peraturan tentang Undang-undang desa yang sering berubah, dan tumpang tindih karena banyak aturan yang mengatur tentang Desa dan Dana Desa, sehingga seringkali merubah kebijakan yang sebelumnya sudah tertata dengan baik.

Hambatan-hambatan tentang pelaksanaan Undang-undang Desa yang dirasakan para aparatur desa di Desa Rancasenggang diatasi dengan mengikuti peraturan yang telah ditetapkan oleh pemerintah Kecamatan Sindangkerta, Kabupaten Bandung Barat, menunggu kejelasan peraturan pemerintah tentang program pembangunan desa, dan menjalin komunikasi sesering mungkin dengan aparatur desa yang lain, dengan camat, dan dengan perintah Kecamatan Sindangkerta, Kabupaten Bandung Barat.

\section{Kesiapan Aparatur Desa dalam Mengimplementasikan Undang- Undang Desa dalam Percepatan Pembangunan Masyarakat Desa di Desa Rancasenggang Kecamatan Sindangkerta, Kabupaten Bandung Barat}

Kesiapan aparatur desa dalam mengimplementasikan undang-undang desa tentunya dimulai dengan melihat potensi yang dimiliki oleh desa, bai k potensi sumber daya alam, maupun sumber daya manusianya. Potensi yang ada kemudian dikelola dengan maksimal untuk pembangunan dan kemajuan desa. Kesiapan aparatur desa dalam mengimplementasikan undang-undang desa dari hasil interview dengan aparatur desa, diketahui bahwa dengan adanya kesepakatan dengan pemerintah Kecamatan Sindangkerta, Kabupaten Bandung Barat, maka implementasi dari undang-undang desa dibatasi pada program perbaikan infrastruktur seperti perbaikan jalan dan irigasi. Sedangkan untuk program lain tidak bisa dilaksanakan.

Karakteristik masyarakat Desa Rancasenggang Kecamatan Sindangkerta, Kabupaten Bandung Barat sangat beragam, dilihat dari agama yang, mayoritas beragama Islam, dan ada juga yang memeluk agama Kristen, tetapi kehidupan bermasyarakat sangat rukun, tidak memandang perbedaan agama sebagai masalah. Dilihat dari mata pencahariaannya, masyarakat di Desa Rancasenggang 
juga beragam, ada yang bekerja sebagai pedagang (khususnya yang tinggal di pinggir jalan desa), petani, buruh pabrik, buruh bangunan, tukang ojek, dan PNS. Tingkat pendidikan di Desa Rancasenggang relatif masih rendah sehingga angka penganggurannya cukup tinggi.

Upaya yang dilakukan untuk mengelola potensi desa di Desa Rancasenggang sudah dilakukan dengan baik, akan tetapi masih selalu dibutuhkan perbaikan, agar potensi yang ada dapat dikelola dengan maksimal, maka peran pemerintah Kecamatan Sindangkerta, Kabupaten Bandung Barat sangat diperlukan, agar upaya untuk meningkatkan tingkat kesejahteraan masyarakat di Desa Rancasenggang dapat tercapai dengan maksimal. Kesiapan aparatur desa harus dimulai dengan pemahaman yang maksimal terkait dengan prosedur dan mekanisme pencairan dana desa hingga pada tahap penggunaan dana desa. Maka diperlukan pemahaman yang maksimal tentang penggunaan dana desa agar tujuan dari diterbitkan undang-undang desa dapat terealisasi dengan baik.

\section{Pembahasan}

Dari bebarapa aspek yang telah diteliti, terkait dengan implementasi dari Undang-undang Desa, hasil penelitian menunjukkan bahwa aparatur desa belum memahami tentang undang-undang desa namun belum maksimal, karena baru dilaksanakan sosialisasi sekali oleh pemerintah Kecamatan Sindangkerta, Kabupaten Bandung Barat, selanjutnya aparatur desa mencoba memahami sendiri undang-undang desa dengan mempelajari buku panduan Undang-undang Desa yang diberikan pada saat sosialisasi oleh pemerintah Kabupaten Bandung Barat. Tujuan sosialisasi dari Undang-undang Desa sebenarnya adalah untuk:

1. menyamakan persepsi tentang peraturan dan kebijakan dalam pelaksanaan Undang-Undang Desa;

2. membangun komitmen bersama antara Pusat dan Daerah dalam membangun desa mandiri sesuai target RPJMN 2015-2019, yaitu mengentaskan minimal 5.000 desa tertinggal dan membangun 2.000 desa mandiri; 
3. menyosialisasikan kebijakan umum dan teknis terkait dengan penguatan pemerintahan desa, pemberdayaan masyarakat, pembangunan desa dan kawasan perdesaan untuk mewujudkan desa mandiri.

Hasil penelitian ternyata sosialisasi Undang-undang Desa hanya dilaksanakan sekali oleh pemerintah Kecamatan Sindangkerta, Kabupaten Bandung Barat, hal ini menjadikan pemahaman para aparatur desa terkait undangundang desa belum maksimal. Sehingga tujuan dari sosialisasi itu sendiri belum bisa dicapai.

Hambatan yang dialami oleh aparatur desa dalam implementasi undangundang desa di Desa Rancasenggang Kecamatan Sindangkerta, Kabupaten Bandung Barat, kurang pahamnya para aparatur desa terhadap undang-undang desa, regulasi atau peraturan tentang undang-undang dan dana desa yang bersifat multitafsir dan seringkali berubah menjadi hambatan bagi aparatur desa. Hal ini juga merupakan hambatan bagi terimplementasikannya Undang-undang desa. Regulasi yang tumpamg tindih tidak hanya menyebabkan perintah desa kebingunan untuk melaksanakan Undang-undang Desa, tetapi juga memberatkan pemerintah desa serta pemerintah kabupaten/kota dalam menyerap dana desa.

Kebijakan yang diambil pemerintah pusat terkait penyederhanaan syarat penggunaan dan desa, maka fokus penggunaan dana desa akan diatur, agar pemerintah desa tidak bingung saat menyusun APBDes, maka penggunaan dana desa difokuskan pada insfrastruktur, irigasi, dan sosial kemasyarakatan. Prosedur pencairan dana desa pemerintah desa cukup menyerahkan dokumen APBdes kepada pemerintah Kabupaten/kota, adapun dokumen lain adalah rencana pembangunan jangka menengah desa (RPJMDes). Menurut UU Desa Pasal 79, pemerintah desa harus menyusun Rencana Pembangunan Jangka Menengah Desa (RPJMDes) untuk jangka waktu 6 tahun dan Rencana Kerja Pemerintah Desa (RKPDes) yang merupakan jabaran RPJMDes tahunan. Selanjutnya dalam Pasal 80 dijelaskan bahwa prioritas kegiatan pembangunan desa meliputi:

1) peningkatan kualitas dan akses terhadap pelayanan dasar;

2) pembangunan dan pemeliharaan infrastruktur dan lingkungan berdasarkan kemampuan teknis dan sumber daya lokal yang tersedia; 
3) pengembangan ekonomi pertanian berskala produktif;

4) pengembangan dan pemanfaatan teknologi tepat guna untuk kemajuan ekonomi; dan

5) peningkatan kualitas ketertiban dan ketentraman masyarakat desa.

Problem terkait dengan dana desa yang lain adalah terkait dengan regulasi yang menghambat pencairan dana desa, di antaranya:

1. Undung-undang nomor 6 tahun 2014 tentang Desa perbedaan sumber penghasilan tetap perangkat desa dalam kedua regulasi ini membuat pencairan dana desa di sejumlah kabupaten terhambat.

2. PP Nomor 43 Tahun 2014 sejumlah desa belum merampungkan Anggaran Pendapatan dan Belanja Desa yang menjadi salah satu syarat pencairan dana desa.

Akan tetapi, syarat pencairan dana desa sudah disederhanakan syarat yang harus dipenuhi oleh pemerintah desa agar dana desa disalurkan. Selain itu hambatan yang lainnya adalah terkait dengan mekanisme pencairan dana desa, pemerintah pusat sudah mentrasfer Rp. 16,61 Triliun ke Kabupaten /kota untuk kemudian di transfer ke masing-masing desa, akan tetapi baru 38.000 desa yang menerima dana tersebut, padahal dana tersebut dapat menggairahkan sektor riil di pedesaaan dapat menumbuhkan perekonomian nasional dan menurunkan tingkat ketimpangan kesejahteraan.

Hambatan lainnya adalah adanya peraturan yang bersifat multitafsir antara 3 kementrian, yaitu:

a. Peraturan Menteri Menteri Desa, Pembangunan Daerah Tertinggal, dan Transmigrasi Nomor 5 tahun 2015 yang menyatakan bahwa dana desa diprioritaskan untuk belanja pembangunan dan pemberdayaan masyarakat desa;

b. Peraturan Menteri Dalam Negeri Nomor 114 tahun 2014 yang menyebutkan dana untuk penyelenggaraan pemerintah desa, pembangunan desa, pembinaa kemasyarakatan desa, dan pemberdayaan masyarakat desa.

c. Permendagri Nomor 113 tahun 2014 meminta desa menyusun laporan realisasi pelaksanaan Anggaran Pendapatan dan Belanja Desa (APBDes), 
sedangkan Menteri keuangan mengatur agar laporan realisasi penggunaan dana desa diajukan setiap akhir semester sehingga aparatur desa harus menyusun dua laporan terpisah.

Semua regulasi tersebut di atas menimbulkan multitafsir dan memberatkan aparat pemerintah desa dan juga pemerintah kabupaten.

Kesiapan aparatur desa dalam implementasikan undang-undang desa di Desa Rancasenggang Kecamatan Sindangkerta, Kabupaten Bandung Barat. Hasil penelitian menunjukkan aparatur desa cenderung pasif karena kebijakan yang sudah dibuat oleh pemerintah Kecamatan Sindangkerta, Kabupaten Bandung Barat. Aparatur desa tidak bisa membuat program sendiri, walaupun sebenarnya aparatur desa sudah mempunyai program yang ingin dilaksanakan untuk kemajuan desa, misalnya pelatihan keterampilan, penuntasan pengangguran, santunan untuk fakir miskin dan jompo, akan tetapi belum bisa terealiasasi karena aturan baru.

Program yang dilaksanakan aparatur desa untuk meningkatkan pembangunan desa di Desa Rancasenggang salah satunya dengan bekerja sama dengan kepala desa yang lain. Hal ini bertujuan untuk bertukar fikiran tentang program yang bisa dilaksanakan oleh aparatur desa untuk kemajuan desa. Misalnya pembangunan jalan, maka membutuhkan koordinasi dengan desa lain terkait dengan batas perbaikan jalan dengan desa yang lainnya. Kegiatan rutin ini sering disebut dengan musyawarah perangkat desa.

Pembangunan desa di Desa Rancasenggang dari hasil penelitian prioritas kegiatan pembangunan desa sesuai dengan Pasal 80 Undang-undang No 6 Th 2014 difokuskan pada point ke 2, yaitu pembangunan dan pemeliharaan infrastruktur dan lingkungan berdasarkan kemampuan teknis dan sumber daya lokal yang tersedia. Point prioritas kegiatan sesuai pasal 80 yang lainnya seperti peningkatan kualitas dan akses terhadap pelayanan dasar, pengembangan ekonomi pertanian berskala produktif, pengembangan dan pemanfaatan teknologi tepat guna untuk kemajuan ekonomi dan peningkatan kualitas ketertiban dan ketentraman masyarakat desa belum dilaksanakan. Hal ini disebabkan program 
pembangunan desa yang dibuat terstruktur sesuai dengan kebijakan pemerintah Kecamatan Sindangkerta, Kabupaten Bandung Barat.

Faktor ketakutan para kepala daerah dan perangkat desa dalam penggunaan dana desa menjadi kendala tersendiri dalam mengimplementasikan Undang-undang Desa di Desa Rancasenggang. Pemerintah desa khawatir tersangkut dengan kasus hukum apabila salah mengeluarkan kebijakan terkait dengan penggunaan dana desa. Padahal pada sisi lain rendahnya penyerapan anggaran membuat sinergi rencana pembangunan pemerintah pusat dan daerah tidak dapat berjalan dengan baik, sehingga pembangunan desa menjadi terhambat. Ketakutan untuk mengambil kebijakan, sinergi pembangungan terganggu, maka otomatis upaya percepatan kesejahteraan masyarakat menjadi ikut terganggu. Aparatur desa menjadi sangat membutuhkan payung hukum terkait penggunaan dana anggaran desa.

Sesuai dengan data yang peneliti peroleh, bahwa pemerintah pusat mengalokasikan dana desa sebesar Rp 20,8 triliun untuk 74.093 desa di Indonesia. Pemerintah pusat sudah mentransfer Rp 16,6 triliun ke kabupaten/kota, tetapi baru sekitar 38.000 desa yang menerima dana itu. Padahal dana itu dapat menggairahkan sektor ril di pedesaan yang diprediksi menumbuhkan perekonomian nasional 0,5 persen dan menurunkan tingkat ketimpangan kesejahteraan (rasio gini) sebesar $0,01^{57}$.

Kementerian Keuangan mencairkan dana desa tahap pertama mencairkan pada April sebesar Rp 8,3 triliun, tahap kedua Rp 8,3 triliun pada bulan Agustus, dan tahap terakhir bulan Oktober sebesar Rp 4,2 triliun. Dengan adanya terbitan (Surat Keputusan Bersama (SKB) maka penggunaan dana desa akan berjalan efektif, dalam hal ini SKB diterbitkan untuk memangkas birokrasi pencairan dana desa, yang nantinya akan memacu penyaluran dan penyerapan dana desa. Seperti yang diketahui dana desa memerlukan persetujuan dari 3 kementrian, yaitu Menteri Dalam Negeri, Menteri Keuangan, dan Menteri Desa, Pembangunan Daerah Tertinggal, dan Transmigrasi.

${ }^{57}$ Kompas 8 september 2015 halaman 1 


\section{Simpulan}

1. Proses sosialisasi Undang-undang No 6 Tahun 2014 tentang Desa di Desa Rancasenggang Kecamatan Sindangkerta, Kabupaten Bandung Barat, dilaksanakan melalui program sosialisasi undang-undang desa yang diselenggarakan pemerintah Kecamatan Sindangkerta, Kabupaten Bandung Barat secara serentak dengan aparatur desa di semua Kecamatan Kecamatan Sindangkerta, Kabupaten Bandung Barat.

2. Hambatan yang dialami oleh aparatur desa dan masyarakat dalam implementasi Undang-undang Desa di Desa Rancasenggang Kecamatan Sindangkerta, Kabupaten Bandung Barat, adalah adanya regulasi yang bersifat multitafsir yang memberatkan pemerintah desa dan pemerintah Kecamatan Sindangkerta, Kabupaten Bandung Barat dalam menyalurkan dana desa.

3. Aparatur desa dalam implementasi undang-undang desa di Desa Rancasenggang Kecamatan Sindangkerta, Kabupaten Bandung Barat, pada dasarnya sudah memahami isi undang-undang desa namun belum maksimal karena sosialisasi undang-undang desa baru dilakukan sekali oleh pemerintah Kecamatan Sindangkerta, Kabupaten Bandung Barat.

\section{DAFTAR PUSTAKA}

Ali, Fauzan, 2010. Implementasi Peraturan Pemerintah Nomor 72 Tahun 2005 tentang Desa Terkait dengan Peran Badan Permusyawaratan Desa dalam Penyusunan dan Penetapan Peraturan Desa di Kecamatan Wanasari, Kabupaten Brebes. Universitas Diponegoro Semarang.

Antono, Herry, 2015, Tentang Kesiapan Desa Mengahadapi Implementasi undang-undang Desa Tinjauan Desentralisasi Fiskal dan Peningkatan Potensi Desa. Jurnal Ilmiah CIVIS, Volume V, No 1, Januari 2015.

Bryant, Coralie dan White Louise,1998. Manajemen Pembangunan. LP3ES, Jakarta.

Benjamin, 2011,. Revitalisasi Pembangunan Desa Melalui Program Rural Infrastrukture Support Program Nasional Pemberdayaan Masyarakat 
Mandiri (RIS PNPM). Jurnal ilmiah Administrasi Publik dan Pembangunan Vol 2.

Dwi, Astuti, 2014. Persepsi Masyarakat terhadap Pelaksanaan UU Nomor 6 Tahun 2014 tentang Desa di Desa Bumiayu Pati. Jurnal ilmiah PPKn Ikip Veteran Semarang.

Iqbal, Hasan, 2004, Analisis Data Penelitian, Jakarta, Bumi Aksara.

I, Wayan Pantiyasa. 2013. Strategi Pengembangan Potensi Desa Menjadi Desa Wisata di Kabupaten Tabanan (Studi Kasus Desa Tegal Linggah, Penebel, Tabanan). Jurnal Ilmiah Hospitality Management, vol. 4.

M. Firman, Hadi. 2013. Hubungan Fungsional Antara Pemerintah Desa dengan BPD dalam Pelaksanaan Pemerintahan Desa Berdasarkan Undangundang Nomor 32 Tahun 2004 tentang Pemerintahan Daerah . Jurnal ilmiah. Fakultas Hukum Universitas Mataram .

Misnaniarti, 2011. Kajian pengembangan desa siaga Di kabupaten ogan ilir Study of the development of alert villages In ogan ilir district. Jurnal Managemen Pelayanan kesehatan. Program Studi Ilmu Kesehatan Masyarakat, Fakultas Kesehatan Masyarakat, Universitas Sriwijaya, Indralaya.

Nazir, Moh, 2005, Metode Penelitian, Bogor, Hlmamania Indonesia.

Nurliana. 2013. Pengelolaan Alokasi Dana Desa (ADD) Dalam Pembangunan fisik di Desa Sukomulyo Kecamatan Sepaku Kabupaten Penajam Paser Utara. Jurnal Administrasi Negara Volume 1, Nomor 3, 2013 : 10591070.Universitas Mulawarman.

Soekanto, Soerjono, 1982, Pengantar Penelitian Hukum, Universitas Indonesia, Jakarta.

Thomas. 2013. Pengelolaan alokasi Dana Desa dalam Upaya Meningkatkan Pembangunan di Desa Sebawang Kecamatan Sesayap Kabupaten Tana Tidung. Jurnal Pemerintah Integratif.

Undang-undang Nomor 6 Tahun 2014 Tentang Desa

Undang-undang Nomor 32 Tahun 2004 tentang Pemerintahan Daerah. 